\title{
The Integration of Lean Management and Six Sigma Strategies to Improve the Performance of Production in Industrial Pharmaceutical
}

\author{
Abdullah Ahmad Al-Shourah ${ }^{1}$, Rawan Thaher Al-Tarawneh ${ }^{2}$ \& Feras Ali Alzu'bi ${ }^{1}$ \\ ${ }^{1}$ Department of Management; Faculty of Finance and Business, The World Islamic University for Sciences \& \\ Education (WISE), Jordan \\ ${ }^{2}$ Department of Industrial Engineering, School of Engineering, The University of Jordan, Jordan \\ Correspondence: Feras Ali Alzu'bi, Department of Management; Faculty of Finance and Business, The World \\ Islamic University for Sciences \& Education (WISE), P.O. Box 1101, 11947 Amman, Jordan. E-mail: \\ falzubi@gmail.com
}

Received: April 25, 2018

doi:10.5539/ijbm.v13n8p207
Accepted: June 4, 2018

Online Published: June 30, 2018

URL: https://doi.org/10.5539/ijbm.v13n8p207

\begin{abstract}
The aim of this paper is to identify the lean management and Six Sigma strategies to improve production performance in pharmaceutical companies through the evaluation and analysis of Six Sigma for the performance of production processes in pharmaceutical companies. The study sheds light on two variables that are considered among the most critical variables in a business organization. The paper explores the critical factors related to the application of L6 $\sigma$. It also, mentions to lean management and six Sigma strategies, analyzing the production process to classify critical areas and work proactively to improve both quality and productivity. The hypotheses of process normality behavior are tested to verify subsistence of adequate conditions for Six Sigma methodology application, as well as errors forecasting in the distribution parameters estimation. The researcher reached several results on the basis of the results of the statistical analysis. The field of Lean Six Sigma had started to produce significantly, standalone concepts of Lean and Six Sigma are highly researched related to the integrated concepts; large proportion of perspective, conceptual and descriptive based studies, empirical validity on the fusion between Lean and Six Sigma. This paper has made an effort to categorize the satisfied of Lean Six Sigma studies that has never before attempted given the complexity and diversity inherent. Therefore, this paper can lookout as abasis for future endeavors in an effort to better the classification and contents in ways that best describe the researches in the field of Lean Six Sigma and six Sigma.
\end{abstract}

Keywords: lean management integration, six sigma performance, Jordanian Pharmaceutical Industries

\section{Introduction}

The definition of Six Sigma has been defined recently by Schroeder Linderman, Liedtke, Choo, (2008) Six Sigma is a structured and parallel structure to reduce variance in organizational processes using optimization specialists and organization method and performance metrics with the goal to achieve strategic objectives. Current developments in the pharmaceutical industry would now be the ideal time to switch to Six Sigma principles. Traditional management tools and functions cannot effectively and efficiently address existing business requirements (Itkin, 2008). This suggests that there are still much for the pharmaceutical industry to gain from Six Sigma and much to be learnt from other industries. This is why large industrial entities constantly develop and implement management tools and systems (Chang, 2006). Six Sigma has become increasingly common in performance management (Schroeder, Linderman, Liedtke \& Choo, 2008). Generally, decided that definition of Six Sigma is a highly disciplined process that focuses on the development and distribution of nearby ideal products and services Grosby (2008).

Six Sigma's core objective is to improve the performance of operations, through operations, as they are based on three things: reducing costs, improving customer satisfaction, increasing returns and ultimately increasing profits (Park, 2003). Sujar et.al (2008) suggests that Six Sigma focuses on customer needs, improved data payment, and processes interventions that result in them: reducing or eliminating defects, reducing deviations in processes, and increasing their capacity. At present, pharmaceutical companies are being tested with problematic responsibilities such as adjusting the unstable and volatile market in times of economic crisis and also to meet the needs of their users in maintaining their health. The additional common definition of Six Sigma is that it is a set of tools and 
techniques to solve problems or improve processes (Das et al., 2008). Some definition of Six Sigma as an improved method keeps a set of tools and techniques together. Pharmaceutical manufacturers are looking at six Sigma principles to significantly improve operational efficiency and quality, while facilitating compliance.

On the other hand, Six Sigma is a continuous improvement plan aimed at reducing variance. Six Sigma derived from Total Quality Management (TQM). Like its predecessor, Six Sigma relies on the use of statistical analysis and other quality tools to identify and eliminate defects but provides a framework for its use and extends its focus beyond quality to other strategic areas of the organization, Antony, Setijono, and Dahlgaard, 2016). Separately, Lean and Six Sigma methodologies often fail to reach results that achieve the enormous improvements that organizations want (Jiju Antony, 2010). By relating the Lean and Six Sigma methodologies, L6 $\sigma$ purposes to attain total customer satisfaction and improved effective effectiveness and efficiency by removing waste and non-value added happenings, declining flaws, falling cycle time and increasing first pass profits (Kanakana, 2010). The neutral of merging the two major techniques is to reduce the cost, regardless of the product and the industry. Six Sigma is a methodology to reduce the number of product defects and to reach organizational excellence (Chakrabarty \& Tan, 2007).

\subsection{The Research Model}

The research model in this paper is the presentation of the impact of Lean management integration and the Six Sigma strategy on improving production performance. The figure below shows the relationship between independent and related variables.

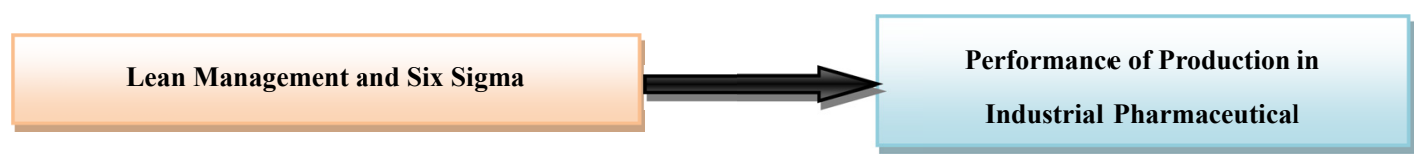

\subsection{Hypothesis}

The research aims to test the improvement of production performance through the application of lean management integration and Six Sigma strategy.

Ho1-2: There is no statistically significant impact of just in time at the level of significance $(\alpha \leq 0.05)$ in improving the performance of production in industrial pharmaceutical.

Ho1-3: There is no statistically significant impact of manufacturing systems at the level of significance $(\alpha \leq 0.05)$ in improving the performance of production in industrial pharmaceutical.

\section{Literature Review}

\subsection{Lean Management and Six Sigma Framework}

This paper proposes the development of an implementation framework roadmap that can be used by implementers of Lean Management and Six Sigma. The literature usage to provide the theory of lean management and six sigma, and to validate the framework components based on critical success factors in the literature. These approaches are critical success factors approach and the diffusion of innovations theory. Categorical to embrace the professional's in the review literature for studies on lean management and six sigma is quiet in its timely phase. Nonetheless the research focus is obviously on the academic literature horizontal. The next stage is to recognize the comfortable of the literature. Three frameworks for implementing Six Sigma were found from our literature search (Sams, 2005; Hayes, 2002; Park, 2003) and one framework for implementing Lean Six Sigma (Furterer, 2004).

\subsection{Six Sigma Implementation and Use}

A shared approach used in developing Six Sigma, Lean management improvement framework is to identify factors or elements that are believed to be critical to the successful implementation of these concepts. We found several studies on critical success factors related to the success of Six Sigma and Lean Six Sigma implementation (Coronado, and Antony, 2002, Burton, and Sams, 2005; Furterer, 2004; Hayes, 2002).

Six Sigma is a business improvement approach that seeks to find and remove the causes of defects or errors in business processes by focusing on process outputs that are important in the judgments of customers (Yin, 2014). Six Sigma principles can be used to transform the average process, helping to create powerful products and processes and minimizing excessive variation in processes that lead to poor quality (Tsironis, Psychogios, \& Cychillar, 2016). At present, six Sigma can be defined as many things, and different people may have different 
meanings. Some will identify six Sigma as a practice aimed at creating a near-complete production process. This explains the recent integration of Lean and Six Sigma (Yadav \& Desai, 2016).

Starting a number of scientific researches on Six Sigma significantly since 2000s, the accepted articles are still specialized in the form of case studies. Similar books and previous articles on the evolution of the development of Six Sigma, then the examples of them have been studied on GE and other successful companies (Rao, 2011).

Burton and Sams, (2005) recognized that, these are started with recognition of the need, provide leadership commitment and support, develop Six Sigma strategy, include initiative wide scope, , make proper investment in resources, develop communication and awareness effort, focus on customer and results, structure around the organization's needs, build a teaming and employee involvement culture, manage controversy, demand frequent measurement, provide recognition and rewards and leverage successes and stay the course. Its trust that these issues have to be in place in order to implement Six Sigma effectively, not just the DMAIC methodology and use of Six Sigma tools.

Chang, (2002) established framework based mostly on the (Malcolm Baldrige National Quality Award) model which contains TQM elements such as strategic planning, leadership, process management, education and training, human resource quality tools, customer management, supplier management and information and analysis. His framework is built around the idea of continuous improvement following MAIC (Measure-Analyse-Improve Control) steps. Chang's development of his framework is rather lacking in discussion about culture consideration related to implementation and the limitations that SMEs can have compared to large organizations.

Useful, mentioned by many researchers who studied Six Sigma, for example, education (Amintava, 2004), food manufacturing, emergency rooms. This topic includes but is not limited to the roles and responsibilities of Six Sigma, project highlights, changing organizational culture (Arthur, 2005), and facial essays specifically Six Sigma (Choo et al., 2007; Schroeder et al., 2008). Hayes, (2002 ) documented that achievement of Six Sigma implementation is based on managerial appointment, management involvement, communications, resources, projects, disciplines and consequences. Furterer, (2004) charted the realization factors of Lean Six Sigma implementation based on her framework components. Six Sigma is the practice of continuous improvement of minimum defects by defining the level of measurement, analysis, optimization and control (DMAIC), developed through the Six Sigma design, which is based on the production of a robust design that meets the requirements of customers (Gutierrez Gutierrez, De Liu, Dobbers, \& Antoni, 2016). These comparisons suggest that Six Sigma is a new approach to the basic productivity of public order (Zhang \& Xu, 2008).

Desai, Anthony and Patel (2011) highlight the critical success factors in implementing Six Sigma in the industry. The results of this investigative study reflect the effects of success factors of Six Sigma. Furthermore, real case study in developing country, Alsmadi, Lehaney and Khan (2012) examine the status of Six Sigma adoption and implementation among the fortune manufacturing and service firms. Reasons behind Six Sigma low implementation resulted from using only classic statistical tools, whereas advanced techniques and methods are less frequently used. Additionally, Delgado et al., (2010) display the results of a survey research carried out of Slovenian manufacturing which focus on common barriers, challenges and serious achievement issues of Six Sigma application. The factors were defined based on literature other than TQM and Six Sigma. "Six Sigma" and "infrastructure" are the most important factors for the success of Six Sigma implementation, followed by

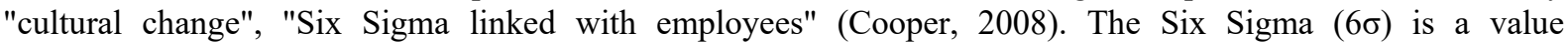
enlargement method that can be value-added in statistical work (Lubowe \& Blitz, 2008). Another, in particular, management-oriented factors include the integrating L6 $\sigma$ with business strategy (Lubowe \& Blitz, 2008; Antony et al., 2011), selection and management of the right project (Breyfogle, 2008), and customer satisfaction (Andel, 2007; Chang-Tseh, 2007). The people-oriented factors include Committed leadership (Carleysmith et al., 2009), Quality-driven Organizational Culture (Koning et al., 2008), training (Delgado et al., 2010), teamwork, and Supportive Technical systems (Psychogios \& Tsironis, 2012).

\subsection{Lean Management and Six Sigma Integration}

The conception of LM and $6 \sigma$ integration began in 1997 when BAE Systems attempted to incorporate LM principles with $6 \sigma$ (Rusko, Králiková, 2011). From the business point of view, Six Sigma can be described as a process that allows organizations to focus heavily on continuous improvements in daily business activities to increase customer satisfaction (Andersson et al., 2006). The concept of lean Six Sigma has not yet matured as an approach to improving the process to a specific stage in academic research (Lee, Tai, \& Sheen, 2013).

Moreover, lean management stands out as a new variable of production management philosophy that opposes the concept of mass production. Six Sigma, for example, when previous studies have shown that companies with 
direct and visible support from top leaders have achieved greater success (Janil, Chauhan, Patel, Sant, \& Patel, 2013). The integrated approach works well than previous tactics because it integrates human (eg leadership, customer focus, cultural change) and process aspects (processing capacity, process management, statistical thinking) to develop actions (Snee, 2010). While there are many units and rapprochement between Lin and Six Sigma, there are some real and substantial differences. Both Lean and Six Sigma rational principles in the real world require knowledge of the various tools and techniques and their demands, not through willpower or simple changes in approach. Professor (Goh, 2011) strongly believes that there are additional positive ways of thinking and tools. Hadid et al. (2016) this look through the verification of the duration of the interaction between Lin language social practices and technical practices against financial performance measures and processes.

Salah et al., (2010) noted that lean management is the formal characterization and organization of experiences and decisions that are not characteristic of Six Sigma. This is why the integration of Lean and Six Sigma is a major enabling factor for this continuous improvement in both producers and distributors. (Yadav \& Desai, 2016), but Anthony (2011) suggests that the integration of Lean and Six Sigma methodologies can produce better results if both methods can achieve even poorer results. Inadequate application of Six Sigma, especially in other alternative contexts, is manufactured separately, particularly in the food processing industry (Kovach \& Cho, 2011).

On the other hand, Lean Six Sigma is a business process and methodology that recovers and improves effective performance, resulting in increased customer satisfaction and improved end results. It is also widely known that Lean Six Sigma is an effective tool for continuous improvement and improvement in driving. Vinodh and Swarnakar (2015) note that "perhaps the greatest advantage of Six Sigma, but the most widely used is its ability to develop a cadre of great leaders" (Snee, 2010). The reasons for the successful use and application of the Six Sigma model have been more successful than the previous quality improvement systems in the pharmaceutical company is that Six Sigma has been implemented at the site with the highest participation from all levels of management and employees. Previous initiatives have been imposed on the site through the functions of international companies, and support and acceptance by the middle management has been low. Roughly say that meager methods do not entail data (AlFawwaz \& Badah, 2012).

Lean tools and techniques - notably value stream mapping, the involvement of people, continuous improvement Tsironis, Psychogios, and Al-Mashari, (2016) and elimination of discarded (Assarlind et al., 2012). The Lean management and Six Sigma a dimensions on the knowledge, methods and tools consequent from times of effective enhancement research and application, concludes that lean management and six sigma progress and history, Lean approaches focus on reducing cost through process optimization. Although six sigma is nearby meeting customer rations, stakeholder prospects and refining quality by measuring and eliminating defects (Byrne et al 2007).

\subsection{Six Sigma Strategies}

Creativities focused on quality have recurrently been accepted at tactical level, focused on projected or cost reduction. Six Sigma actions must be supported by processes and structures to ensure they move business objective advancing (Gamal, 2010). Though, the strategic possible is far greater; strategically Six Sigma has the potential to help organizations develop what called organizational capability. Strategic Six Sigma types the determination put into vision building and strategic planning pay off by linking these activities right to operational plans and Six Sigma projects which deliver tangible results. Strategic Six Sigma revenues Six Sigma and strategic planning to an exclusively new place where neither approach can go alone (Habidin, Yusof, \& Fuzi, 2016). Six Sigma is a strategy it is widely spreading and accessible by most organization (Alsmadi and Khan, 2010). It is a disciplined, data-driven approach and it has a methodology for eliminating defects in any process from manufacturing to transactional, from products to services. This improvement strategy delivers results of productivity, profitability and quality improvements based on its highly effective approach (Desai, et.al, 2011).

These types of Sigma synths are achieved in capacity building and planning to raise the performance level by implementing these programs. Achieving a performance level of six sigma for labor may be costly because "the effort and difficulty increase exponentially with the increased sigma process." There is a need for more sophisticated statistical tools and knowledge to reach the level of performance $6 \sigma$. The benefits and expected return on investment may be prior to the commencement of this project (Kanigolla, Cudney, Corns, \& Samaranayake, 2014) Six Sigma Customs Method Zkur After the PDK phase in deming, DMAIC may be either measuring, analyzing, optimizing, (Schroeder, Linderman, Liedtke, \& Choo, 2008).

But it is still the main actors in the organization carefully watching, which can not be displayed on the dashboard, but they are not exposed to leaders without justification (Zou, Robbins \& Friedendhal, 2010). However, it is 
recommended to be cautious with initial investments in the training of well-defined river specialists (Kumar et al., 2008). The Shakravorti study (2009) suggests that six Sigma programs fail to send sequences of different Six Sigma components in organizations. Moreover, it seems that the implementation and application itself prevents companies from accessing the full potential of Six Sigma and take advantage of their potential to improve the process successfully, (Zou et al., 2008).

\subsection{Six Sigma and Performance Improves}

The Six Sigma Development Law outlines how the process is performed. Experimental confirmation of the value of Six Sigma is of great importance. The terms of the technical effects that supports the stump. After all, Six Sigma is the last management; the ultimate test is wherever it can lead to better performance (Ashkins, 2012). A large experimental test is needed to have consequences in Six Sigma. The utility benefits six weeks. Recent efforts to identify and measure six Sigma have laid a solid foundation for large-scale experimental studies (Schroedward, 2008).

The least used tools in the organizations are the quality diffusion function, the publishing policy, the Kano model, the design of experiments, the control of statistical processes, and the error of checking the farmer-duka. Experimental studies must also be accompanied by varying dimensions and levels. Their effects can be unbreakable or traumatic. Possession of the nobility: short term versus long term (Jirasukprasert et al., 2014). Performance, compare strategy Lean Six Sigma provides an explanation that creates more flexible, robust and cost-effective processes. The strategic father of Sigma is the next step in the development of Six Sigma and strategic planning. Six Sigma revolves around the management and tactics applied within the current regulatory package. Six Sigma strategies revolve around strategic features. (Neely, Gregory, \& Platts, 2005).

\section{Research Methodology}

The study used the descriptive and analytical method and adopted the (simple random sampling), to analyze the study population which consists of all Pharmaceutical industry in the Amman Stock Exchange. Instrument Reliability is the consistency of the measurement which is the used questionnaire, or the degree to which an instrument measures the same way each time it is used under the same condition with the same subjects, it can be proofed by testing the reliability of the questionnaire, Cronbach's Alpha was used and the results revealed as shown in table (1).

\subsection{The Importance of Methodology}

The degree to which the method is measured by itself each time its right under the same situation with the same data, can be proved on the path of a reliable product in the questionnaire, was used Alpha Kronbach and revealed the results as shown in Table 1.

Table 1. Alpha Cronbach and revealed the results

\begin{tabular}{ll}
\hline Cronbach's Alpha \% & Dimensions \\
\hline 91.2 & Lean management and Six Sigma \\
91.0 & Quality programs. \\
90.5 & Just in time \\
92.7 & Manufacturing systems \\
95.1 & Performance of production \\
\hline
\end{tabular}

Subsequently Table 1 shown that the results revealed a Cronbach's alpha coefficient was between (95.1\%) to (0.905) for all constructs, since the acceptable values should be more than $(60 \%)$ according to (Sekaran \& Bougie, 2010), was more than (0.8). This section presents testing of the main hypothesis along with it sub hypotheses, using simple linear regression test to finally reject or accept each, as explained in the following sections.

Ho1: There is no statistically significant impact of lean management and Six Sigma at the level of significance $(\alpha \leq 0.05)$ in Improving the Performance of Production in Pharmaceutical Companies in the Amman Stock Exchange. 
Table 2. Simple Regression - impact of lean management and six sigma in improving the performance of production

\begin{tabular}{|c|c|c|c|c|c|c|c|c|c|c|}
\hline \multicolumn{5}{|c|}{ Coeffecient } & \multicolumn{3}{|c|}{ ANOVA } & \multicolumn{3}{|c|}{ Model Summery } \\
\hline Sig $t^{*}$ & $\mathbf{T}$ & $\begin{array}{c}\text { Standard } \\
\text { error }\end{array}$ & B & DATA & $\operatorname{Sig} \mathrm{F}^{*}$ & Df & $\mathbf{F}$ & $\mathbf{r}^{2}$ & $\mathbf{R}$ & $\begin{array}{c}\text { dependent } \\
\text { variable }\end{array}$ \\
\hline .000 & 25.296 & .031 & .775 & $\begin{array}{c}\text { lean } \\
\text { manageme } \\
\text { nt and Six } \\
\text { Sigma }\end{array}$ & .000 & 1 & 644.939 & .565 & .752 & $\begin{array}{l}\text { performance } \\
\text { of production }\end{array}$ \\
\hline
\end{tabular}

The provided results in above table 2 shown that the value of $(\mathrm{r}=.752)$ which indicate that there are appositive strong size effect between (lean management and Six Sigma) and (Improving the Performance of Production). While $(\mathrm{R} 2=.565)$ (also called the coefficient of determination), which is the proportion of variance in (the Performance of Production) that can be explained by (lean management and Six Sigma). Accordingly, (lean management and Six Sigma) explain (56.5\%) of the variability of (the Performance of Production).

Based on the foregoing, the level of $(F)$ in the model was reached (644.939) within the significant levels $(\mathrm{Sig}=0.000)$ and this result confirms the regression model statistically significantly predict the outcome variable at $(\alpha \leq 0.05)$. Beta value have reached $(B=0.775)$ with $(T=25.296)$ at the significant level $(\operatorname{sig}=0.000)$, this confirms coefficients are statistically significant to the model at $(\alpha \leq 0.05)$ level. Based on these results, null hypotheses should be rejected and accept the alternative hypotheses mention that:

"There is a statistically significant impact of lean management and Six Sigma at the level of significance ( $\alpha \leq 0.05)$ in Improving the Performance of Production in Pharmaceutical Companies in Amman Stock Exchange"

Ho1-1: There is no statistically significant impact of Quality Programs at the level of significance $(\alpha \leq 0.05)$ in Improving the Performance of Production in Pharmaceutical Companies in Amman Stock Exchange.

Table 3. Simple Regression - impact of quality programs in improving the performance of production

\begin{tabular}{ccccccccccc}
\hline & & Coeffecient & & & \multicolumn{3}{c}{ ANOVA } & \multicolumn{2}{c}{ Model Summery } \\
\hline Sig t* & $\mathbf{T}$ & $\begin{array}{c}\text { Standard } \\
\text { error }\end{array}$ & B & DATA & Sig F* & Df & F & r2 & R & $\begin{array}{c}\text { dependent } \\
\text { variable }\end{array}$ \\
\hline .000 & 25.295 & .029 & .744 & $\begin{array}{c}\text { Quality } \\
\text { Programs }\end{array}$ & .000 & 1 & 639.818 & .563 & .751 & $\begin{array}{c}\text { Performance } \\
\text { of Production }\end{array}$ \\
\hline
\end{tabular}

The provided results in above table (3) shown that the value of $(\mathrm{r}=.751)$ which indicate that there are appositive strong size effect between (quality programs) and (Improving the Performance of Production).

While $(\mathrm{R} 2=.563)$ the coefficient of determination, which is the proportion of variance in (the Performance of Production) that can be explained by (quality programs). Accordingly, (quality programs) explain (56.3\%) of the variability of (the Performance of Production).

Based on the foregoing, the level of (F) in the model was reached (639.818) within the significant levels (Sig=0.000) and this result confirms the regression model statistically significantly predict the outcome variable at $(\alpha \leq 0.05)$. Beta value have reached $(B=0.744)$ with $(\mathrm{T}=25.295)$ at the significant level $($ sig $=0.000)$, this confirms coefficients are statistically significant to the model at $(\alpha \leq 0.05)$. Founded on these results, null hypotheses should be rejected and accept the alternative hypotheses that discuss;

"There is a statistically significant impact of quality programs at the level of significance ( $a \leq 0.05)$ in Improving the Performance of Production in Pharmaceutical Companies in the Amman Stock Exchange”.

Ho1-2: There is no statistically significant impact of Just in Time at the level of significance $(\alpha \leq 0.05)$ in Improving the Performance of Production in Pharmaceutical Companies in Amman Stock Exchange. 
Table 4. Simple Regression - Impact of just in time in improving the performance of production

\begin{tabular}{ccccccccccc}
\hline Sig $\mathbf{t}^{*}$ & $\mathbf{T}$ & $\begin{array}{c}\text { Coeffecient } \\
\text { Standard } \\
\text { error }\end{array}$ & B & DATA & Sig F* & Df & F & r2 & R & $\begin{array}{c}\text { dependent } \\
\text { variable }\end{array}$ \\
\hline .000 & 22.926 & .032 & .723 & $\begin{array}{c}\text { Just In } \\
\text { Time }\end{array}$ & .000 & 1 & 12.212 & .514 & .717 & $\begin{array}{c}\text { Performance of } \\
\text { Production }\end{array}$ \\
\hline
\end{tabular}

The provided results in above table 4 shown that the value of $(\mathrm{r}=.717)$ which indicate that there are appositive strong size effect between (JIT) and (Improving the Performance of Production). While (R2=.514) the coefficient of determination, which is the proportion of variance in (the Performance of Production) that can be explained by (JIT). Accordingly, (JIT) explain (51.4\%) of the variability of (the Performance of Production).

Formed on the foregoing, the level of (F) in the model was reached (12.212) within the significant levels $(\mathrm{Sig}=0.000)$ and this result confirms the regression model statistically significantly predict the outcome variable at $(\alpha \leq 0.05)$. Beta value have reached $(B=0.723)$ with $(T=22.926)$ at the significant level $(\mathrm{sig}=0.000)$, this confirms coefficients are statistically significant to the model at $(\alpha \leq 0.05)$. Founded on these results, the second sub-null hypotheses should be rejected and accept the alternative hypotheses state that;

"There is a statistically significant impact of just in time at the level of significance $(\alpha \leq 0.05)$ in Improving the Performance of Production in Pharmaceutical Companies in the Amman Stock Exchange”.

Ho1-3: There is no statistically significant impact of Manufacturing Systems at the level of significance $(\alpha \leq 0.05)$ in Improving the Performance of Production in Pharmaceutical Companies in the Amman Stock Exchange.

Table (5) Simple Regression - Impact of Manufacturing Systems in Improving the Performance of Production

\begin{tabular}{ccccccccccc}
\hline & & Coefficient & & & & ANOVA & & Model Summery & $\begin{array}{c}\text { dependent } \\
\text { variable }\end{array}$ \\
Sig t* & T & $\begin{array}{c}\text { Standard } \\
\text { error }\end{array}$ & B & DATA & Sig F* & Df & F & r2 & R & Performance of \\
Production
\end{tabular}

The provided results in above table 4 shown that the value of $(\mathrm{r}=.727)$ which indicate that there are appositive strong size effect. While $(\mathrm{R} 2=.532)$ the coefficient of determination, which is the proportion of variance in (the Performance of Production) that can be explained by (Manufacturing Systems). Accordingly, (Manufacturing Systems) explain (53.2\%) of the variability of (the Performance of Production).

Based on the foregoing, the level of (F) in the model was reached (562.943) within the significant levels $(\mathrm{Sig}=0.000)$ and this result confirms the regression model statistically significantly predict the outcome variable at $(\alpha \leq 0.05)$. Beta value have reached $(B=0.679)$ with $(T=23.726)$ at the significant level $(\mathrm{sig}=0.000)$, this confirms coefficients are statistically significant to the model at $(\alpha \leq 0.05)$ level. Founded on these results, the third sub-null hypotheses should be rejected and accept the alternative hypotheses that refer:

"There is a statistically significant impact of Manufacturing Systems at the level of significance $(\alpha \leq 0.05)$ in Improving the Performance of Production in Pharmaceutical Companies in the Amman Stock Exchange".

\section{Conclusion}

Six Sigma has been widely practiced by species by a long organization of time but its search is still in its early stages. In many different contexts, the extensive record of it has eased researchers' concerns and heightened research interest, as evidenced by the recent number of articles on Six Sigma. This is a sincere apprehension but it seems to be the dimensions of scientific research efforts on Six Sigma. Furthermore, Six Sigma is actually anticipated as a useful medication. In many different contexts, the record of Six Sigma has eased researchers' concerns and enhanced research interest, as evidenced by the recent number of articles on Six Sigma. One of the views is about integrating lean management and replacing it. However, Six Sigma emphasizes optimization, an exploitative activity. The management of the laboratory should take six Sigma methodologies by showing the date of work. This L6 $\sigma$ can be implemented to any kind of industry, for better performance, L6 $\sigma$ is a continuous improvement tool for betterment. There are many areas of future research related to the Lean Six Sigma roadmap. 
The framework roadmap can be validated against other processes.

\section{References}

AlFawwaz, T., \& Badah, A. (2012). Using Six Sigma to Evaluate the Administrative Performance of Vocational and Technical Training Institutions in Jordan. International Journal of Business and Management, 7(20). https://doi.org/10.5539/ijbm.v7n20p90

Alsmadi, L., \& Khan. (2012). A comparative analysis of Lean practices and performance in the UK manufacturing and service sector firms. Total Quality Management \& Business Excellence, 23(3-4). 381-396. https://doi.org/10.1080/14783363.2012.669993

Andel, T. (2007). Lean and Six Sigma Traps to Avoid. Material Handlin Management, 62(3), 23-28.

Andersson, R., Eriksson, H., \& Torstensson, H. (2006). Similarities and differences between TQM, six sigma and lean. The TQM Magazine, 18(3), 282-96. https://doi.org/10.1108/09544780610660004

Antony, J., Krishan, N., Cullen, D., \& Kumar, M., (2011). Lean Six Sigma for Higher Education Institutions (HEIs): Challenges, Barriers, Success Factors, Tools/Techniques. International Journal of Productivity and Performance Management, 61(8). https://doi.org/10.1108/17410401211277165

Antony, J., Setijono, D., \& Dahlgaard, J. J. (2016). Lean Six Sigma and innovation-an exploratory study among UK organizations. Total Quality Management \& Business Excellence, 27(1/2), 124-140. https://doi.org/10.1080/14783363.2014.959255

Arthur, J. (2005). Six Sigma simplified-quantum improvements made easy, Life Star, Colorado, US. Breakthrough Management Group (2001) Six Sigma-An Overview, Denver, US. https://doi.org/10.1504/IJSSCA.2005.006424

Assarlind, M., Gremyr, I., \& Bäckman, K. (2012). Multi-faceted views on a Lean Six Sigma application. International Journal of Quality \& Reliability Management, 30(4), 387-402. http://dx.doi.org/10.1108/02656711311308385

Breyfogle, F. (2008). Implementing Six Sigma: Smarter Solutions Using Statistical Methods (2nd ed.). New Jersey: NJ, John Wiley \& Sons.

Burton, T. T., \& Sams, J. L. (2005). Six Sigma for Small and Mid-sized Organizations. Florida: J. Ross Publishing.

Byrne, G., Lubowe, D., \& Blitz, A. (2007). Using a lean Six Sigma approach to drive innovation. Strategy \& Leadership, 35(2), 5-10. https://doi.org/10.1108/10878570710734480

Carleysmith, S. W., Dufton, A. M., \& Altria, K. D. (2009). Implementing lean sigma in pharmaceutical research and development: A review by practitioners. R\&D Management, $39,1$. https://doi.org/10.1111/j.1467-9310.2008.00542

Chakrabarty, A., \& Tan, K. C. (2007). The current state of six sigma application in services. Managing Service Quality, 17(2), 194-208. https://doi.org/10.1108/09604520710735191

Chang, H. (2006). An Empirical evaluation of performance measurement systems for total quality management. Total Quality Management \& Business Excellence, 17(8), 1093-1109. https://doi.org/10.1080/14783360600941795

Chang, T. L. (2002). Six Sigma: A framework for small and medium sized enterprises to achieve total quality. Unpublished doctoral dissertation, Cleveland State University, Ohio, USA. https://doi.org/10.1504/IJSSCA.2011.039719

Chang-Tseh, H., Lin, B., \& Manduca, B. (2007). Information Technology and Six Sigma Implementation. Journal of Computer Information Systems, 47(4) 1-10. https://doi.org/10.1080/08874417.2007.11645975

Choo, A. S., Linderman, K. W., \& Schroeder, R. G. (2007). Method and context perspectives on learning and knowledge creation in quality management. $J$ of $O M$, 25(4). https://doi.org/10.1016/j.jom.2006.08.002

Coronado, R. B., \& Antony, J. (2002). Critical success factors for the successful implementation of six sigma projects in organizations. The TQM Magazine, 14(2), 92-9. https://doi.org/10.1108/09544780210416702

Das, A., Pagell, M., Behm, M., \& Veltri, A. (2008). Toward a theory of the linkages between safety and quality. Journal of Operations Management, 26(4), 521-535. https://doi.org/10.1016/j.jom.2007.06.005

Delgado, C., Ferreira, M., \& Branco, M. C. (2010). The implementation of Lean Six Sigma in financial services 
organizations. Journal of Manufacturing Technology Management, 21(4), 512-523. https://doi.org/10.1108/17410381011046616

Desai, D. A., Antony, J., \& Patel, M. B. (2011). Six Sigma implementation in Indian industries An assessment of the critical success factors for Six Sigma implementation in Indian industries. International Journal of $\begin{array}{llll}\text { Productivity } \quad \text { and } & \text { Management, } & \text { 61(4), }\end{array}$ https://doi.org/10.1108/17410401211212670

Furterer, S. L. (2004). A framework roadmap for implementation lean six sigma in local government entities. Unpublished $\mathrm{PhD}$ dissertation. University of Central Florida, Orlando, USA.

Goh T. N. (2011). Adoption of Six Sigma in smaller organizations. International Business: Innovation. Psychology, Economics, 2(1), 34-40.

Gutierrez, G. L., de Leeuw, S., Dubbers, R., \& Antony, J. (2016). Logistics services and Lean Six Sigma implementation: a case study. International Journal of Lean Six Sigma, 7(3). https://doi.org/10.1108/IJLSS-05-2015-0019

Habidin, N. F., Yusof, S. M., \& Fuzi, N. M., (2016). Lean Six Sigma, strategic control systems, and organizational performance for automotive suppliers. International Journal of Lean Six Sigma, 7(2). https://doi.org/10.1108/IJLSS-04-2015-0013

Hadid, W., Mansouri, S. A., \& Gallear, D. (2016). Is lean service promising? A socio-technical perspective. International Journal of Operations \& Production Management, 36(6), 618-642. https://doi.org/10.1108/IJOPM-01-2015-0008

Hayes, B. J. (2002). Six sigma critical success factors, I Six Sigma. Retrieved from http://www.isxsigma.com

Itkin, D. (2008). The effect of business ownership change on occupational employment and wages. Monthly Labor Review, 131(9), 3-23.

Janil, P., Chauhan, S., Patel, G., Sant, L., \& Patel, D. (2013). Sigma six: a quality control tool in pharma industry. International Journal of Universal Pharmacy and Bio Sciences, 2, 59-69.

Jiju, A. (2010). Six Sigma vs Lean some perspectives from leading academics and practitioners. https://doi.org/10.1108/17410401111101494

Jirasukprasert, G. R., \& Kumar, L. (2014). A Six Sigma and DMAIC application for the reduction of defects in a rubber gloves manufacturing process. International Journal of Lean Six Sigma, 5(1), 2-21. https://doi.org/10.1108/IJLSS-03-2013-0020

Kanakana, M. G. (2010). Lean Six Sigma Framework to Improve Throughput rate. https://doi.org/10.1109/ICIEEM.2010.5646488

Kanigolla, D., Cudney, E., Corns, S., \& Samaranayake, V. (2014). Enhancing engineering education using project-based learning for Lean and Six Sigma. International Journal of Lean Six Sigma, 5(1), 45-61. https://doi.org/10.1108/IJLSS-02-2013-0008

Koning, D. H., Does, R. J. M. M., \& Bisgaard, S. (2008). Lean Six Sigma in financial services. International Journal of Six Sigma and Competitive Advantage, 4(1), 1-17. https://doi.org/10.1504/IJSSCA.2008.018417

Kovach, T., \& Cho, R. (2011). Better processes make GOOD EATS: Food industry can benefit from lean Six Sigma principles. Industrial Engineer: IE, 43(1), 36-40.

Kumar, M., Upadhyay, S., Ogbu, C., \& Antony, J. (2008). An investigation of Six Sigma implementation within UK manufacturing SMEs: Findings from the survey, First European Research Conference on Continuous Improvement and Lean Six Sigma. https://doi.org/10.1108/02656710810898658

Lee, K. L., Tai, C. T., \& Sheen, G. J. (2013). Using LSS to improve the efficiency and quality of a refund process in a logistics center. International Journal of Lean Six Sigma, 4(4), 409-424. https://doi.org/10.1108/IJLSS-04-2013-0023

Linderman, K. W., Schroeder, R. G., \& Choo, A. S. (2008). Six Sigma: the role of goals in improvement teams. Journal of Operations Management, 24(6), 779-790. https://doi.org/10.1016/j.jom.2005.08.005

Neely, A. D., Gregory, M. J., \& Platts, K. W. (2005). Performance measurement system design, a literature review and research agenda. International Journal of Operations \& Production Management, 25(12), 1228-63. https://doi.org/10.1108/01443579510083622

Park, S. (2003). Six Sigma for Quality and Productivity Promotion. Tokyo: Asian Productivity Organization. 
Psychogios A., \& Tsironis, L. (2012). Understanding the implementation of Lean Six Sigma in Context: Lessons from Service Industry. TQM \& Business Excellence. https://doi.org/10.1108/02656711211190909

Psychogios, G. A., \& Wilkinson, A. (2007). Exploring TQM awareness in the Greek national business context: Between conservatism and reformism cultural determinants of TQM. The International Journal of Human Resource Management, 18(6), 1042-1062. https://doi.org/10.1080/09585190701321666

Rao, J. (2011). Best buy: Merging lean sigma with innovation. Harvard Business Review. https://doi.org/10.1111/1468-0009.12023

Rusko, M., \& Králiková, R. (2011). Application of Six Sigma Method to EMS Design, Faculty of Materials Science and Technology in Trnava. https://doi.org/10.2478/v10186-010-0037-8

Salah, S., Rahim, A., \& Carretero, J. A. (2010). The integration of Six Sigma and Lean management. International Journal of Lean Six Sigma, 1(3), 249-274. https://doi.org/10.1108/20401461011075035

Saunders, M., Lewis, P., \& Thornhill, A. (2016). Research Methods for Business Students (7th ed.). Edinburgh: Pearson Education Limited. https://doi.org/10.1080/14783363.2014.959255

Schroeder, R. G., Linderman, K., Liedtke, C., \& Choo, A. S. (2008). Six Sigma: Definition and Underlying Theory. Journal of Operations Management, 26, 536-554. https://doi.org/10.1016/j.jom.2007.06.007

Sekaran, U., \& Bougie, R. (2010). Research Method of Business: A Skill Building Approach. John Willey \& Sons, New York, NY. https://doi.org/10.1108/00251741011090289

Sewing, A. et al. (2008). Helping science to succeed: Improving processes in R\&D. Drug Discov. Today, 13, 227-233. https://doi.org/10.1016/j.drudis.2007.11.011

Sheffi, Y. (2007). The resilient enterprise: Overcoming vulnerability for competitive advantage. Cambridge: MIT.

Snee, R. D. (2010). Lean Six Sigma - getting better all the time. International Journal of Lean Six Sigma, 1(1), 9-29. https://doi.org/10.1108/20401461011033130

Taner, M. T. (2012). A feasibility study for Six Sigma implementation in Turkish textile SMEs. South East European Journal of Economics and Business, 7(1), 63-72. https://doi.org/10.2478/v10033-012-0006-6

Tsironis, L. K., Psychogios, A., \& Al-Mashari, M. (2016). Road towards Lean Six Sigma in service industry: Amulet-factor integrated framework. Business Process Management Journal, 22(4). https://doi.org/10.1108/BPMJ-08-2015-0118

Vinodh, S., \& Swarnakar, V. (2015). Lean Six Sigma project selection using hybrid approach based on fuzzy DEMATEL-TOPSIS. International Journal of Lean Six Sigma, 6(4). https://doi.org/10.1108/IJLSS-12-2014-0041

Yadav, G., \& Desai, T. N. (2016). Lean Six Sigma: a categorized review of the literature. International Journal of Lean Six Sigma, 7(1), 2-24. https://doi.org/10.1108/IJLSS-05-2015-0015

Yin, R. K. (2014). Case Study Research - Design and Methods (5th ed.). Thousand Oaks: SAGE Publications, Inc. https:// doi.org/10.1177/1356389013497081

Zhang, W., \& Xu, X. (2008). Six Sigma and information system (IS) project management: A revised theoretical model. Project Management Journal, 39(3), 59-74. https://doi.org/10.1002/pmj.20066

\section{Copyrights}

Copyright for this article is retained by the author(s), with first publication rights granted to the journal.

This is an open-access article distributed under the terms and conditions of the Creative Commons Attribution license (http://creativecommons.org/licenses/by/4.0/). 